\title{
Non-syndromic and non-familial type of multiple basal cell carcinoma over unusual site.
}

\author{
Dr.Rajeev Ranjan ${ }^{1}$, Dr,.Amit Kumar ${ }^{2}$, Dr.Shrinivas Radder ${ }^{3}$, \\ Dr.Prof.Ranjan George Baxla ${ }^{4,}$ Dr.Ranveer Singh Rana ${ }^{5,}$ Dr. Manish Kumar ${ }^{6}$ \\ 1,2,4,56, (Department of General Surgery, Rajendra Institute of Medical SciencesRanchi, India) \\ ${ }_{3}^{3}$ (Department of radiodiagnosis, Rajendra Institute of Medical SciencesRanchi, India)
}

\begin{abstract}
We report a case of multiple basal cell carcinoma in a patient of albinism. which was non-familial, non-syndromic and having no history of chemical exposure. A 58 year old male with 4 lesions one over the left scapula $(5 * 5 C M)$ for 4 years, over the right shoulder $3 * 2 C M$ for 3 and half years, over the right elbow $2 * 2 C M$ and $1 * 2 C M$ for 3 years. Family history of basal cell carcinoma, xerodermapigmentosa and features of gorlin"s syndrome were absent, thats why, this is a rare case of multiple basal cell carcinoma which occurred in absence of familial, and various chemical exposure mentioned in standard literature
\end{abstract}

Keywords :Non-familial, non-syndromic, xerodermapigmentosa, gorlin's syndrome, multiple basal cell carcinoma.

\section{Introduction}

Basal cell cancer is the most common cancer skin cancer occur as a single skin lesion Occur as a single lesion ,mainly over the face and neck.multiple basal cell cancer can occur with syndromicassociation,familial history or chemical exposure.

\subsection{AIMS/OBJECTIVES}

\section{Heading}

This is a case report of very rare and unique nonsyndromic non heriditary and absence of various other environmental condition of multiple basal cell carcinoma over back and arm.

\subsection{METHOD}

58 years old man,lightskinned,farmer by occupation no history of arsenic intake,herb medication or exposure to chemical warfare gases..nofamily history of xerodermapigmentosa and basal cell carcinoma. there was 4 lessions $5 * 5 \mathrm{CM}$ over the left scapula for 4 years, $2 * 2 \mathrm{CM}$ over dorsal aspect of right elbow, $3 * 2 \mathrm{CM}$ over the right shoulder and satellite lession over the right scapula with no lymphadenopathy for 3 and half months.wide excision of lession with $1 \mathrm{CM}$ tumor free margin and skin grafting was done the excised tissue sent for histopathological examination for tumor free margin.the case report is supported with $\mathrm{CBC}, \mathrm{R} / \mathrm{E}$ of urine, blood sugar ,renal profile,ECG.diagnostic skin biopsy and histopathological report ,chest x-ray, liver function test.

\subsection{RESULT}

Post-operative period was uneventfull and satisfactory till discharge and there was no signs of recurrence after 1 month of follow up 


\section{FIGURES}

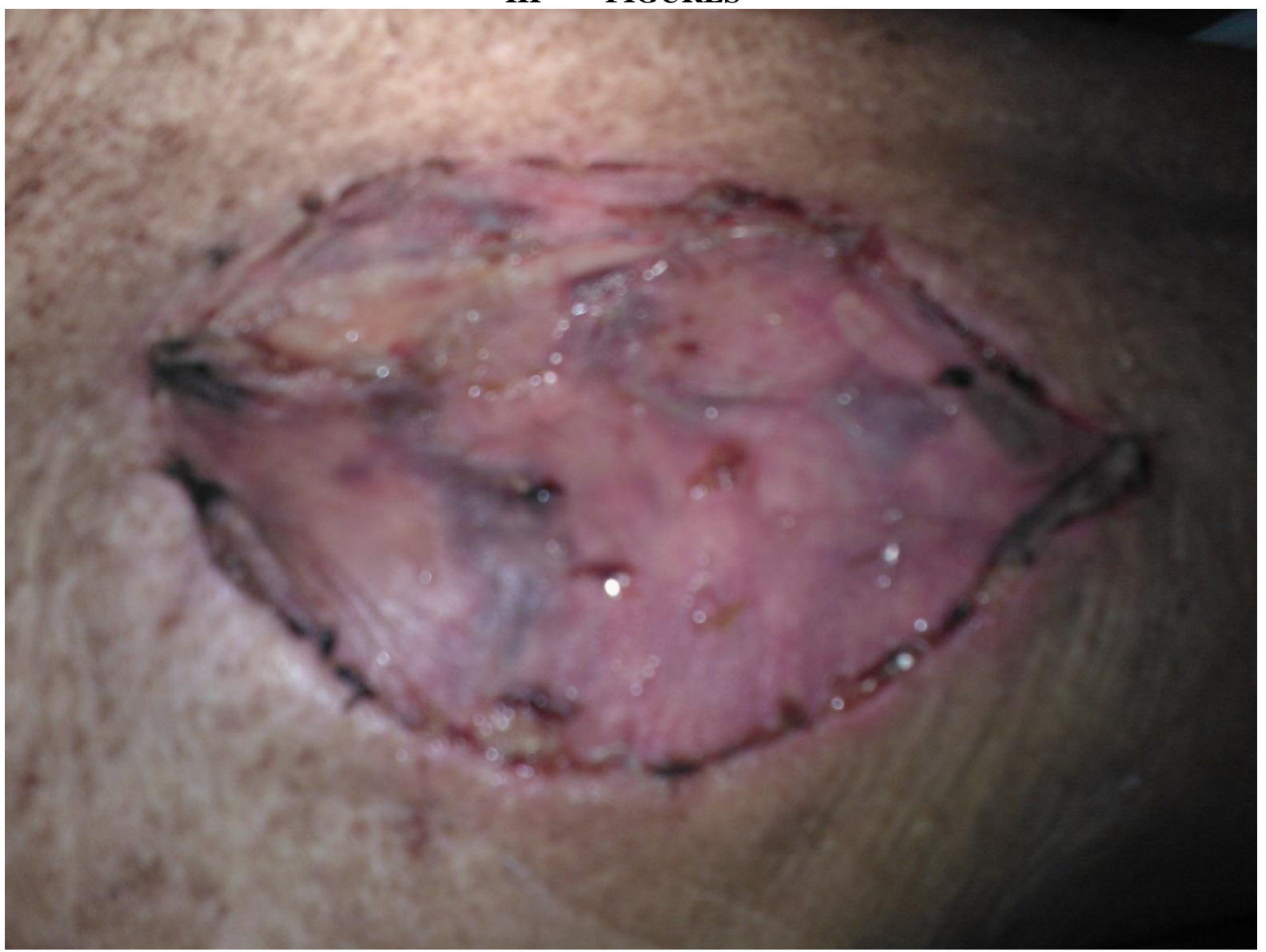

Fig. 1: After excision of scapular lesion \& the tissue is sent for histopathological examination

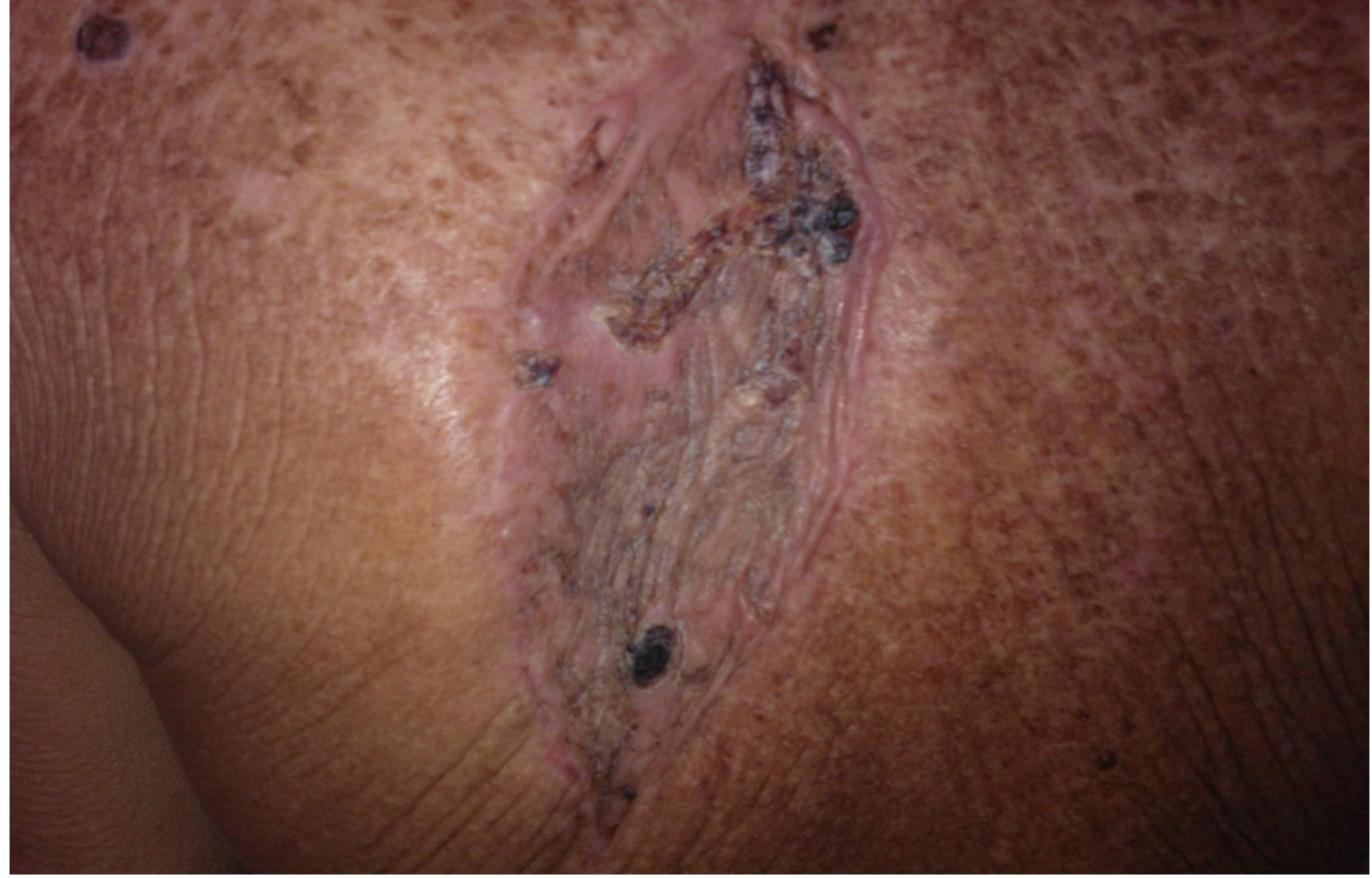

Fig. 2: Scapular lesion in healing phase 


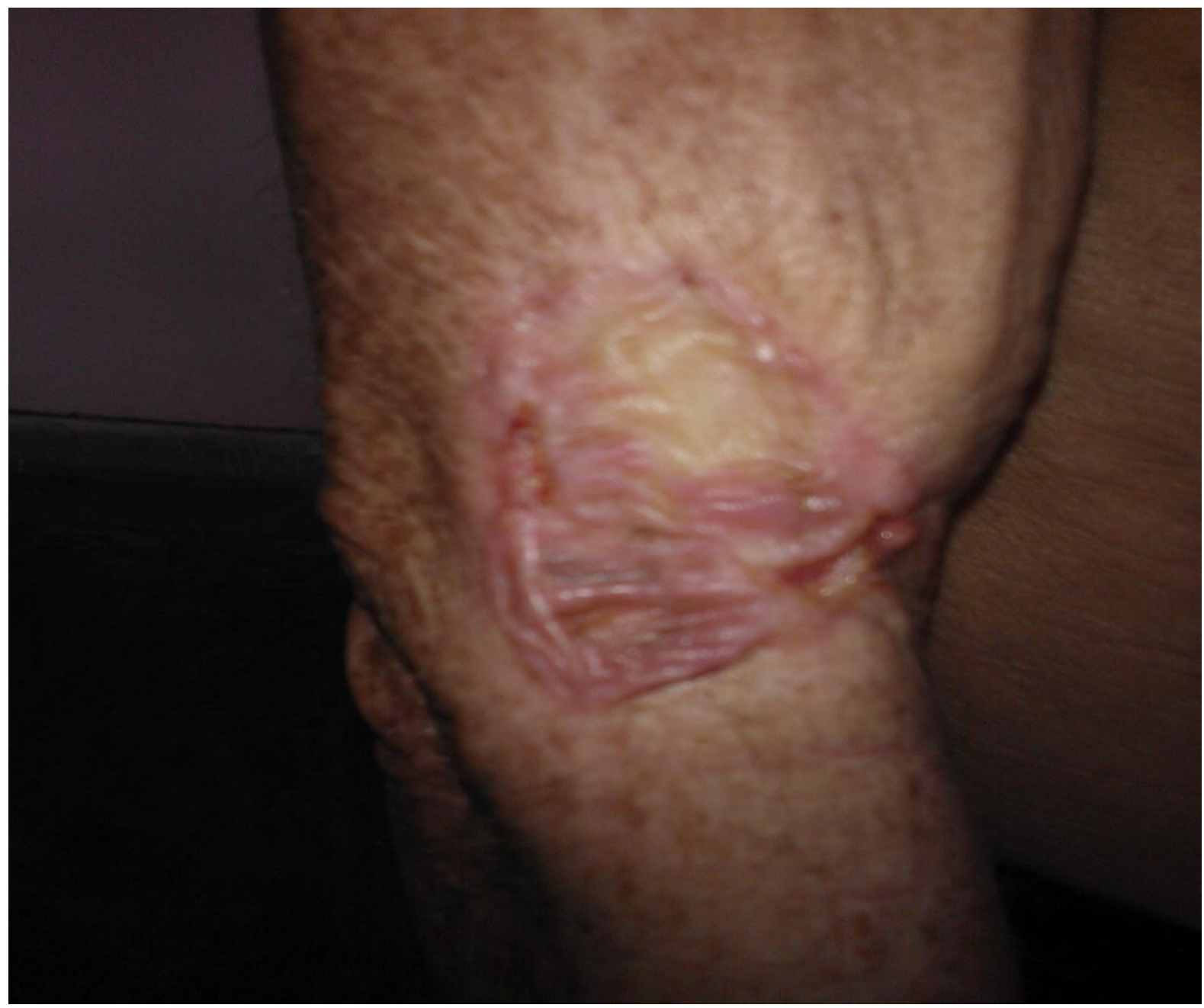

Fig. 3: Elbow lesion after excision and grafting

\section{CONCLUSION}

This is a case report of multiple basal cell carcinoma with non-syndromic, non-familial association and no exposure to environmental condition over the unusual site.optimal treatment for this condition is wide local excision and skin grafting that has been done in this case.

\section{Acknowledgements}

The author would like to acknowledge Dr Prof.N.K.Jha, Head of Department of surgery, for his guidance and support.

\section{Journal papper}

\section{References}

[1]. Alessi SS, Sanches JA, Oliveira WR, Messina MC, Pimentel ER, FestaNeto C. Treatment of cutaneous tumors with topical 5\% imiquimod cream. Clinics (Sao Paulo).2009;64:961-6. [PMC free artic]

[2]. Bree AF, Shah MR. BCNS Colloquium Group; Consensus statement from the first international colloquium on basal cell nevus syndrome (BCNS). Am J Med Genet A. 2011;155A:2091-7. [PubMed]

[3]. Cowan R, Hoban P, Kelsey A, Birch JM, Gattamaneni R, Evans DG. The gene for the naevoid basal cell carcinoma syndrome acts as a tumour-suppressor gene in medulloblastoma. Br J Cancer. 1997;76:141-5. [PMC free article] [PubMed]

[4]. Debeer P, Devriendt K. Early recognition of basal cell naevus syndrome.Eur J Pediatr. 2005;164:123-5. [PubMed]

[5]. Evans DG, Birch JM, Orton CI. Brain tumours and the occurrence of severe invasive basal cell carcinoma in first degree relatives with Gorlin syndrome.Br J Neurosurg. 1991a;5:643-6. [PubMed] 